\title{
EDITORIAL
}

\section{Early detection: introduction}

\author{
M. Decramer*, C. Roussos\#
}

The present Supplement of the European Respiratory Journal assembles a number of reviews on "Early detection" and it is the product of a symposium held in Barcelona on June 22 2002. The symposium was organised by the European Institute of Healthcare, which was set up by AstraZeneca. It was the fourth symposium of this kind organised by this Institute. The goals of the Institute were extensively discussed in Supplement nos. 34, 35 and 36 [1-3].

The programme of this symposium was designed by an independent programme committee. The core of this committee comprises the two editors of the present Supplement and other members of the committee include: C. Brambilla (Grenoble, France), R. Loddenkemper (Berlin, Germany), R. RodriguezRoisin (Barcelona, Spain), O. Van Schayck (Maastricht, the Netherlands) and M. Woodhead (Manchester, UK). The cornerstones of the commitment of AstraZeneca to these symposia are basically fourfold: 1) the symposia are not product related; 2) the company has no influence on the scientific programme; 3) scientific excellence is the goal; 4) the symposia consist of a mixture of basic science and clinical medicine. They are primarily directed at chest physicians who are able to cascade down the information distributed at the symposia in their respective countries. They carry the interest of the European Respiratory Journal because of the clear commitment to scientific excellence and independence.

Early detection is without question a significant issue in respiratory disease. There is now overwhelming evidence that many cases of airflow obstruction are undiagnosed in the general population [4-6]. Office spirometry in general practice may contribute to a better detection of airflow obstruction [7]. Earlier detection is likely to improve outcome in asthma [8], as postponing treatment with inhaled corticosteroids may cause deterioration in airway inflammation [9]. Whether this is also associated with irreversible effects on lung function is not yet clear. At present, it is not clear whether early detection and treatment will improve outcome in chronic obstructive pulmonary disease (COPD). Indeed, the only treatment at present that has been shown to affect the progression

\footnotetext{
*Respiratory Division, University Hospital, Katholieke Universiteit Leuven, Leuven, Belgium. ${ }^{\#}$ Critical Care, Pulmonary Division and Evangelismos Hospital, Athens, Greece

Correspondence: M. Decramer, Respiratory Division, University Hospital, Herestraat 49, B-3000 Leuven, Belgium. Fax: 32 16346803. E-mail: Marc.Decramer@uz.kuleuven.ac.be
}

of COPD is smoking cessation [10]. Smoking cessation is indicated even if not for COPD, for the risk of lung cancer or ischaemic heart disease. Although several treatments affect the health status of COPD patients [11-13] or the occurrence of exacerbations [11], a hard core demonstration of a better outcome after early treatment is still missing. Although, on average, respiratory scientists still tend to be sceptical, indirect evidence indicates that COPD treatment has resulted in improved survival over the last 20 yrs [14]. Strictly, however, a demonstration of the usefulness of early therapeutic intervention is not available at present. It is likely that this question will be an important area of research in years to come.

Likewise, early detection of lung cancer appears an attractive strategy. Indeed, the prognosis of stage III lung cancer remains poor despite the clear progress that has been made with chemotherapy. Earlier detection appears a logical approach to improving the overall outcome of treatment. Early detection could be achieved through spiral computed tomography (CT) for peripheral lesions or sputum cytology for central lesions [15]. The latter technique unfortunately has a low sensitivity and is time consuming. Fluorescent bronchoscopy may increase the detection rate of microinvasive lesions. Biomarkers in blood and sputum appear interesting, but still lack validation [15]. Differentiation from benign lesions remains a serious problem and limits the current clinical usefulness of spiral CT [16]. Progress in imaging techniques and processing may be of help in this differentiation. They may be some important evolutions in this field in the years to come. Further development of new techniques, such as endobronchial ultrasonography, optical coherence tomography, confocal micro-endoscopy, positron emission tomography in combination with video-assisted thoracic surgery and intraluminal bronchoscopic treatments, is also expected to play an important role [17].

The present supplement covers several aspects of early detection. It begins with an overview of the general principles of screening and early detection by BOYLE [18]. Early detection of asthma and COPD in general practice is then addressed by VAN SCHAYCK and Chavannes [8]. As asthma and COPD are often first diagnosed in general practice, an improvement in treatment largely depends upon whether or not general practitioners follow asthma and COPD guidelines. PARTRIDGE [19] discusses the general principles involved in adherence to guidelines and the general obstacles for general practitioners with guidelines. 
Here, it is important to note that physicians, on average, do not appear to follow guidelines $[20,21]$ and that publication of a guideline alone is not enough for implementation [22]. BuIsT [23] then puts early treatment into the perspective of the current treatment of COPD and asthma.

Next, the early detection of lung cancer is addressed. BrAmBILLA et al. [15] discuss the use of biomarkers in the early detection of lung cancer. Henschke et al. [24] discuss the use of low-dose computed tomography and new imaging procession methods in the early detection of lung cancer. SPIRO [25] discusses the current treatment of lung cancer with emphasis on early treatment and finally SUTEDJA [17] discusses new techniques, primarily endoscopic in nature, for the detection and treatment of lung cancer.

\section{References}

1. Decramer M, Roussos CS, Rodriguez-Roisin R, eds. Cytokines and obstructive lung disease. Eur Respir $J$ 2001; 18: Suppl. 34.

2. Decramer M, Roussos CS, eds. Imaging in lung disease. Eur Respir J 2001; 18: Suppl. 35.

3. Decramer M, Roussos CS, R Loddenkemper, eds. Respiratory infections and tuberculosis. Eur Respir $J$ 2002; 20: Suppl. 36.

4. Pauwels RA, Buist AS, Calverley PMA, Jenkins CR, Hurd SS. Global strategy for the diagnosis, management, and prevention of chronic obstructive pulmonary disease: NHLBI/WHO Global Initiative for Chronic Obstructive Lung Disease (GOLD) Workshop summary. Am J Respir Crit Care Med 2001; 163 : 1256-1276.

5. Mannino DM, Gagnon RC, Petty TL, Lydick E. Obstructive lung disease and low lung function in adults in the United States: data from the National Health and Nutrition Examination Survey, 19881994. Arch Intern Med 2000; 160: 1683-1689.

6. Coultas DB, Mapel D, Gagnon R, Lydick L. The health impact of undiagnosed airflow obstruction in a national sample of United States adults. Am J Respir Crit Care Med 2001; 164: 372-377.

7. Buffels J, Degryse J, Heyrman J, Decramer M. Office spirometry improves early detection of COPD in general practice: the DIDASCO study. $A m J R$ CCM 2002; 165: A654.

8. van Schayck CP, Chavannes NH. Detection of asthma and chronic obstructive pulmonary disease in primary care. Eur Respir J 2003; 21: Suppl. 39, 16s-22s.

9. Haahtela T, Järvinen M, T Kata, et al. Effects of reducing or discontinuing inhaled budesonide in patients with mild asthma. $N$ Engl J Med 1994; 331: 700-705.

10. Anthonisen NR, Connett JE, Kiley JP, et al. Effects of smoking intervention and the use of anticholinergic bronchodilator on the rate of decline of FEV1. The lung health study. JAMA 1994; 272: 1497-1505.

11. Burge PS, Calverley PM, Jones PW, Spencer S, Anderson JA, Maslen TK. Randomised double blind placebo controlled study of fluticasone propionate in patients with moderate to severe chronic obstructive pulmonary disease: the ISOLDE trial. $B M J 2000 ; 320$ : 1297-1303.

12. Jones PW, Bosh TK. Quality of life changes in COPD patients treated with salmeterol. Am J Respir Crit Care Med 1997; 155: 1283-1289.

13. Vincken W, van Noord JA, Greefhorst APM, et al. Improved health outcomes in patients with COPD during $1 \mathrm{yr}^{\prime}$ s treatment with tiotropium. Eur Respir $J$ 2002; 19: 209-216.

14. Rennard S, Carrera M, Agusti A. Management of chronic obstructive pulmonary disease: are we going anywhere? Eur Respir J 2000; 16: 1035-1036.

15. Brambilla C, Fievet F, Jeanmart M, et al. Early detection of lung cancer: role of biomarkers. Eur Respir J 2003; 21: Suppl. 39, 36s-44s.

16. Swenson SJ, Jett JR, Sloan JA, et al. Screening for lung cancer with low-dose spiral computed tomography. Am J Respir Crit Care Med 2002; 165: 508513.

17. Sutedja G. New techniques for early detection of lung cancer. Eur Respir J 2003; 21: Suppl. 39, 57s-66s.

18. Boyle P. Screening. Eur Respir J 2003; 21: Suppl. 39, 3s-15s.

19. Partridge MR. Translating research into practice: how are guidelines implemented? Eur Respir J 2003; 21: Suppl. 39, 23s-29s.

20. Cabana MD, Rand CS, Powe NR, et al. Why don't physicians follow clinical practice guidelines? A framework for improvement. JAMA 1999; 282: $1458-1465$.

21. Freeman AC, Sweeney K. Why general practitioners do not implement evidence: a qualitative study. $B M J$ 2001; 323: 1100-1102.

22. Grimshaw JM, Russel IT. Achieving health gain through clinical guidelines: developing scientifically valid guidelines. Qual Health Care 1993; 4: 243-248.

23. Buist AS. Similarities and differences between asthma and chronic obstructive pulmonary disease: treatment and early outcomes. Eur Respir J 2003; 21: Suppl. 39, $30 \mathrm{~s}-35 \mathrm{~s}$.

24. Henschke CI, Yankelevitz DF, McCauley DI, Libby DM, Pasmantier MW, Smith JP. Guidelines for the use of spiral computed tomography in screening for lung cancer. Eur Respir J 2003; 21: Suppl. 39, 45s-51s.

25. Spiro SG. Surgery for nonsmall cell lung cancer: can improvements be made? Eur Respir J 2003; 21: Suppl. 39, 52s-56s. 